\title{
Change in heritability estimates due to half-sib family selection in the maize variety Pahari
}

\author{
M. Noor ${ }^{1}$, D. Shahwar', H. Rahman', H. Ullah' ${ }^{2}$, F. Ali ${ }^{3,4}$, M. Iqbal $^{3}$, \\ I.A. Shah ${ }^{3}$ and I. Ullah ${ }^{5}$ \\ 'Department of Plant Breeding and Genetics, University Agricultural, \\ Peshawar, Pakistan \\ ${ }^{2}$ Faculty of Agriculture, Abdul Wali Khan University, Mardan, Pakistan \\ ${ }^{3}$ Cereal Crops Research Institute, Pirsabak, Nowshera, \\ Khyber Pakhtunkhwa, Pakistan \\ ${ }^{4}$ National Key Laboratory of Crop Improvement and Genetics, \\ Huazhong Agricultural University, Wuhan, China \\ ${ }^{5}$ Department of Plant Science, Kohat University of Science and Technology, \\ Kohat, Pakistan
}

Corresponding authors: D. Shahwar / M. Noor

E-mail: smartyashmak@yahoo.com / noor_pbg49@yahoo.com

Genet. Mol. Res. 12 (2): 1872-1881 (2013)

Received July 4, 2012

Accepted November 9, 2012

Published January 16, 2013

DOI http://dx.doi.org/10.4238/2013.January.16.1

ABSTRACT. This research was carried out at the Agriculture Research Farm, Khyber Pakhtunkhwa Agricultural University, Peshawar, and the Cereal Crops Research Institute, Pirsabak, Nowshera, during 2009 and 2010. Half-sib families (HS) derived from the maize variety Pahari in spring crop seasons 2009 and 2010 were developed at the Cereal Crops Research Institute. All HS families were detasseled well before pollen shedding. At maturity, each family was harvested and shelled separately. During the summer crop of seasons 2009 and 2010, these HS families were evaluated in $12 \times 12$ and $11 \times 11$ partially balanced lattice square arrangements at the Khyber Pakhtunkhwa Agricultural University, Peshawar, for various flowering and yield traits, respectively. The data on days to mid-silking, anthesis, anthesis-silking interval, 100-grain weight, 
and grain yield were recorded. The results revealed significant differences among families for all traits in both cycles. High heritability $(0.88)$ was observed for days to mid-silking in cycle $0\left(\mathrm{C}_{0}\right)$, while moderate heritability (0.42) was recorded for 100-grain weight in $\mathrm{C}_{1}$. The selection differential was quite reasonable and varied according to the traits of interest. The observed response for grain yield in $\mathrm{C}_{0}(815.74 \mathrm{~kg} / \mathrm{ha})$ was greater than the expected response $(681.76 \mathrm{~kg} / \mathrm{ha})$.

Key words: Maize; Half-sib; Recurrent selection; Pahari; Heritability; Khyber Pakhtunkhwa

\section{INTRODUCTION}

Maize is a multipurpose crop. In Asia, maize is grown in Pakistan, India, and Nepal as a food, feed, and fodder crop. It is also produced in Indonesia and Thailand, but is not a preferred human food in these countries. It is the major staple food in many countries in Latin America and Africa. Approximately two-thirds of the total world production of maize is used for livestock feed or for commercial starch and oil production (Khalil and Jan, 2002). It has great nutritional value as it contains approximately $66.7 \%$ starch, $10 \%$ protein, $4.8 \%$ oil, $8.5 \%$ fiber, 3\% sugar, and 7\% ash (Chaudhry, 1983).

Maize breeders have used several methods of maize improvement, particularly mass selection, modified ear-to-row selection, $\mathrm{S}_{1}$ line, reciprocal, and full- and half-sib (HS) recurrent selection (RS) methods to develop high-yielding maize varieties with improved yield per unit area. In any RS program, progress from selection is directly related to the expected change in allelic frequency and the magnitude of genetic variance in the breeding population (Helms et al., 1989). Therefore, population improvement through recurrent methodology focuses on two main objectives: first, improvement of the mean performance of a population through an increase in the frequency of favorable alleles, and second, maintaining adequate genetic variability in the improved population for continued selection and genetic improvement in subsequent generations. Evaluation of RS programs can lead to increased knowledge of methods, population, and traits and provide support for better management of breeding programs (Guimaraes, 2001). Realized progress with any breeding scheme, however, depends largely upon the ability of the breeder to identify superior genotypes and the accuracy with which the experiments are conducted (Alam, 1999). The $\mathrm{S}_{1}$ progeny selection and HS family selection are of particular interest in this regard (Tanner and Smith, 1987; Beavis et al., 1994).

"HS" is defined as the progeny from a cross that has one parent in common. In maize population improvement, grain yield has historically been the most important trait and hence the most frequently selected. Previous estimates for grain yield improvement indicated that one may expect to observe a $2-4 \%$ increase per cycle in grain yield for different methods of selection in different populations, the same methods in different populations, or different methods in the same population, depending on the type of method used for selection (CIMMYT, 1981). Eyherabide and Hallauer (1991) reported a 6.5\% per cycle increase in grain yield for a population cross in a reciprocal full-sib selection program between BS10 (formerly Iowa two-ear synthetic) and BS11 (formerly Pioneer two-ear composite). Keertinijakal and Lamkey (1993) also reported a 7.0\% per cycle increase in yield in the population cross between Iowa Stiff Stalk Synthetic (BSSS) and 
Iowa Corn Borer Synthetic No. 1 (BSCB1). Lamkey (1992) reported that 7 cycles of HS family selection in BSSS increased grain yield by $3.9 \%$ per cycle, whereas 6 cycles of $\mathrm{S}_{2}$ progeny selection following 7 cycles of HS selection produced no increase.

Identification of superior genotypes in a mixed or base population is one of the major aims of plant breeders (Khan, 2004). The objectives of this study were to evaluate HS families derived from the maize variety Pahari and to identify superior HS families for yield and yieldrelated traits that can be used in future maize breeding programs.

\section{MATERIAL AND METHODS}

The procedure, material, and methods used in the present study are as follows.

\section{Breeding material}

The breeding materials used in this experiment comprised 144 and 121 HS lines developed from the maize variety Pahari in 2009 and 2010, respectively. Pahari is a composite of Shaheen x PS-7930. It is a white, semi-dent variety of medium-tall stature, and semi-dense tassel with profuse branching. The base population was used as a control.

\section{Procedure and field experiment}

During the spring crop seasons (March-June) of 2009-2010, 144 and 121 HS lines derived from the maize variety Pahari were developed by growing the selected HS lines with composite males of selected HS lines in isolation at the Cereal Crops Research Institute, Pirsabak, Nowshera. Regular visits to the farm were made to detassel female lines that displayed tassels. The detasseled HS lines were allowed to be pollinated naturally by the bulk male lines. Plants were hand-harvested at physiological maturity (black layer formation at hilum of maize kernel). HS lines with maximum grain filling, ear length, and good-looking cobs were selected, while the rest were discarded. During the summer of 2009 and 2010, HS lines, along with one check, were evaluated in a replicate trial using a partially balanced lattice square design with 2 replications at the Agricultural University Peshawar research farm. Row length was kept at $5 \mathrm{~m}$, with 0.25 -m plant-to-plant spacing and $0.75-\mathrm{m}$ row-to-row spacing. At the 4 to 6 leaf stage, the number of plants was reduced to one plant per hill through thinning to maintain a population size of 53,300 plants per hectare. Standard cultural practices were carried out in both seasons. Fertilizer was applied in the form of diammonium phosphate and urea at the rate of 125 and $250 \mathrm{~kg} / \mathrm{ha}$, respectively. All of the diammonium phosphate was applied at the time of sowing, while half the urea was applied before sowing, with the rest being applied when plants were at knee height. The crop was irrigated weekly. Data were recorded for the following parameters as and when appropriate: days to mid-silking, midanthesis, anthesis-silking interval (ASI), 100-grain weight (g), and grain yield (kg/ha).

\section{ASI}

The ASI was calculated with the following formula on a per-plot basis: ASI $=$ days to $50 \%$ silking - days to $50 \%$ pollen shedding 


\section{Grain yield (kg/ha)}

Grain yield was calculated from the data of fresh ear weight per plot with the following formula (Carangal et al., 1971):

$$
\text { Grain yield }(\mathrm{kg} / \mathrm{ha})(15 \% \mathrm{GM})=\frac{\text { Freshear weight }(\mathrm{kg} / \mathrm{plot}) \times(100-\mathrm{MC}) \times 0.8 \times 10,000}{(100-15) \times \text { Area harvested (plot size })}
$$

where $G M$ is the grain moisture; $M C$ is the moisture content (\%) in grains at harvest; 0.8 is the shelling coefficient; area per plot is $3.75 \mathrm{~m}^{2} ; 1$ hectare is $10,000 \mathrm{~m}^{2} ; 15 \%$ is the moisture content required in grain at storage.

\section{Statistical analysis}

Analysis of variance (ANOVA) based on a randomized complete block design was computed according to format (Table 1) for the data of each year and trait (Milles et al., 1980) to derive mean squares for HS families using the MSTATC computer package (Director Crop and Siol Science Department, Machigan State University, Version 2.00).

Table 1. ANOVA format for single cycle.
\begin{tabular}{lccc} 
\\
\hline SOV & d.f. & MS & Expected MS \\
\hline Replication $(\mathrm{r})$ & $\mathrm{r}-1$ & & \\
Block $(\mathrm{k})$ & $\mathrm{r}(\mathrm{k}-1)$ & $\mathrm{M} 2$ & $\sigma_{\mathrm{E}}^{2}+\mathrm{r}^{2}{ }_{\mathrm{G}}$ \\
Treatments & $\left(\mathrm{k}^{2}-1\right)$ & $\mathrm{M} 1$ & $\sigma_{\mathrm{E}}^{2}$ \\
Error & $(\mathrm{k}-1)(\mathrm{rk}-\mathrm{k}-1)$ & \\
\hline
\end{tabular}

$\mathrm{SOV}=$ source of variation; d.f. $=$ degrees of freedom; $\mathrm{MS}=$ mean square.

Estimates of genotypic and phenotypic components were calculated from ANOVA and used to calculate heritability on an entry-mean basis (Penny and Elbert, 1971; Carson et al., 2004) as follows:

$\delta^{2} \mathrm{e}=\mathrm{M} 1$ (error mean squares)

$\delta^{2} \mathrm{e}+\mathrm{r} \delta^{2} \mathrm{G}=\mathrm{M} 2$ (genotypic/families mean squares)

$\delta^{2} \mathrm{G}=\mathrm{M} 2-\mathrm{M} 1$ [genotypic variance $\left(\delta^{2} \mathrm{G}\right)$ ]

$\delta^{2} \mathrm{G}+\delta_{\mathrm{E} / \mathrm{r}}^{2}=$ phenotypic variance $\left(\delta^{2} \mathrm{P}\right)$

$\mathrm{h}^{2}{ }_{\mathrm{BS}}=$ broad-sense heritability

$\mathrm{h}^{2}{ }_{\mathrm{BS}}=\delta^{2} \mathrm{~g} / \delta^{2} \mathrm{~g}+\delta^{2} \mathrm{e}($ Fehr, 1987)

The selection differential was calculated as:

$$
\mathrm{S}=\mu_{\mathrm{HS}}-\mu,
$$

where $S$ is the selection differential; $\mu_{H S}$ is the mean of selected HS families; $\mu$ is the population mean.

The expected response (Re) was calculated as:

$$
\mathrm{Re}=\mathrm{S} \times \mathrm{h}^{2}
$$

The observed response (Ro) was calculated by subtracting the population mean from the mean of the progenies of the selected $S_{1}$ lines $\left(\mu_{\mathrm{P}}\right)$ (Lush, 1940):

$$
\mathrm{Ro}=\mathrm{R}_{\mathrm{o}}=\mu_{\mathrm{P}}-\mu
$$


The percent gain per selection was estimated as follows (Keeling, 1982):

\section{RESULTS}

$$
\% \text { gain per cycle }(C)=\frac{\mathrm{C}_{1}-\mathrm{C}_{0}}{\mathrm{C}_{0}} \times 100
$$

\section{Flowering traits}

Highly significant differences $(\mathrm{P} \leq 0.01)$ were observed in both $\mathrm{C}_{0}$ and $\mathrm{C}_{1}$ among the $\mathrm{HS}$ families for days to mid-silking, anthesis, and ASI (Table 2). High and moderate heritability estimates were observed for all flowering traits in both $C_{0}$ and $C_{1}$ (Table 2). The mean values for days to mid-silking, anthesis, and ASI in $\mathrm{C}_{0}$ were $48.39,47.59$, and 0.79 , respectively. Similarly in $\mathrm{C}_{1}$, the mean values for flowering were $49.88,49.42$, and 0.45 , respectively (Table 3 ). The selection differential for days to mid-silking, anthesis, and ASI in $\mathrm{C}_{0}$ was $0.61,0.61$, and 0.01 , respectively. Similarly in $\mathrm{C}_{1}$, the selection differential values for days to mid-silking, anthesis, and ASI were $-0.57,-0.38$, and -0.16 , respectively (Table 2 ). The $\mathrm{Re}$ in $\mathrm{C}_{0}$ for days to mid-silking, anthesis, and ASI were $0.54,0.45$, and 0.00 , respectively (Table 2). Similarly in $\mathrm{C}_{1}$, the expected responses for flowering traits were $-0.33,-0.18$, and -0.07 , respectively (Table 2 ). The Ro for days to mid-silking, anthesis, and ASI in $\mathrm{C}_{0}$ was $0.61,0.61$, and 0.21 , respectively (Table 3 ). The gain per cycle for days to mid-silking, anthesis, and ASI was $3.08,3.85$, and $-43.04 \%$, respectively (Table 3 ). Days to mid-silking was positively correlated with days to mid-anthesis, ASI, and grain yield, while it was negatively and highly significantly correlated with 100 -grain weight in $\mathrm{C}_{0}$. Similarly, days to mid-silking in $\mathrm{C}_{1}$ was positively and significantly correlated with days to mid-anthesis and ASI. Days to mid-anthesis was positively and highly significantly correlated with ASI and grain yield in $\mathrm{C}_{0}$, while it negatively correlated with 100-grain weight. Likewise, days to mid-anthesis in $\mathrm{C}_{1}$ was positively and significantly correlated with ASI (Table 4).

Table 2. Mean square values, heritability $\left(\mathrm{h}^{2}{ }_{\mathrm{BS}}\right)$, selection differential $(\mathrm{S})$, and expected response (Re) for various parameters observed during $\mathrm{C}_{0}$ and $\mathrm{C}_{1}$ in maize population Pahari.

\begin{tabular}{|c|c|c|c|c|c|c|c|c|}
\hline \multirow[t]{2}{*}{ Parameter } & \multicolumn{2}{|c|}{ Mean squares } & \multicolumn{2}{|c|}{$\mathrm{h}^{2}{ }_{\mathrm{BS}}$} & \multicolumn{2}{|c|}{$\mathrm{S}$} & \multicolumn{2}{|c|}{$\mathrm{Re}$} \\
\hline & $\mathrm{C}_{0}$ & $\mathrm{C}_{1}$ & $\mathrm{C}_{0}$ & $\mathrm{C}_{1}$ & $\mathrm{C}_{0}$ & $\mathrm{C}_{1}$ & $\mathrm{C}_{0}$ & $\mathrm{C}_{1}$ \\
\hline Days to silking & $9.94 * *$ & $6.01 * *$ & 0.88 & 0.57 & 0.61 & -0.57 & 0.54 & -0.33 \\
\hline Days to anthesis & $5.34 * *$ & $2.48 * *$ & 0.74 & 0.48 & 0.61 & -0.38 & 0.45 & -0.18 \\
\hline Anthesis silking interval & $2.37 * *$ & $2.39 * *$ & 0.48 & 0.45 & 0.01 & -0.16 & 0.00 & -0.07 \\
\hline 100 -grain weight $(\mathrm{g})$ & $12.11^{* *}$ & $16.75^{*}$ & 0.59 & 0.42 & 0.67 & 0.98 & 0.39 & 0.41 \\
\hline Grain yield $(\mathrm{kg} / \mathrm{ha})$ & $1274827.78^{* *}$ & $676804.11^{* *}$ & 0.74 & 0.64 & 927.22 & 639.84 & 681.76 & $410.20 * *$ \\
\hline
\end{tabular}

**Highly significant; *significant.

Table 3. Means of population ( $\mu$ ), selected half-sib families ( $\mu \mathrm{HS}$ ), progeny $(\mu \mathrm{P})$, observed response (Ro), and gain/cycle for different parameters observed during $\mathrm{C}_{0}$ and $\mathrm{C}_{1}$ in maize population Pahari.

\begin{tabular}{|c|c|c|c|c|c|c|c|}
\hline \multirow[t]{2}{*}{ Parameter } & \multicolumn{2}{|c|}{$\mu$} & \multicolumn{2}{|c|}{$\mu \mathrm{HS}$} & \multirow{2}{*}{$\begin{array}{l}\mu \mathrm{P} \\
\mathrm{C}_{1}\end{array}$} & \multirow{2}{*}{$\begin{array}{l}\text { Ro } \\
\mathrm{C}_{0}\end{array}$} & \multirow[t]{2}{*}{ Gain (\%) } \\
\hline & $\mathrm{C}_{0}$ & $\mathrm{C}_{1}$ & $\mathrm{C}_{0}$ & $\mathrm{C}_{1}$ & & & \\
\hline Days to silking & 48.39 & 49.88 & 49.00 & 49.31 & 49.00 & 0.61 & 3.08 \\
\hline Days to anthesis & 47.59 & 49.42 & 48.20 & 49.04 & 48.20 & 0.61 & 3.85 \\
\hline Anthesis silking interval & 0.79 & 0.45 & 0.80 & 0.29 & 1.00 & 0.21 & -43.04 \\
\hline 100-grain weight (g) & 25.26 & 27.33 & 25.93 & 28.31 & 25.93 & 0.67 & 8.19 \\
\hline Grain yield $(\mathrm{kg} / \mathrm{ha})$ & 3150.61 & 3309.26 & 4077.83 & 3949.10 & 3966.00 & 815.74 & 5.05 \\
\hline
\end{tabular}


Table 4. Phenotypic correlation among flowering and grain yield-related traits in cycle 0 (above diagonal) and cycle 1 (below diagonal).

\begin{tabular}{|c|c|c|c|c|c|}
\hline & DS & DA & ASI & GWT & YLD \\
\hline DS & - & $0.86^{* * *}$ & $0.67 * *$ & $-0.23 * *$ & $0.13^{*}$ \\
\hline $\mathrm{DA}$ & $0.76 * *$ & - & $0.19 * *$ & $-0.16 * *$ & $0.17 * *$ \\
\hline ASI & $0.75 * *$ & $0.14^{*}$ & - & $-0.21 * *$ & $0.002^{\mathrm{NS}}$ \\
\hline GWT & $-0.05^{\mathrm{NS}}$ & $-0.05^{\mathrm{NS}}$ & $-0.03^{\mathrm{NS}}$ & - & $0.24 * *$ \\
\hline YLD & $-0.09^{\mathrm{NS}}$ & $-0.09^{\mathrm{NS}}$ & $-0.04^{\mathrm{NS}}$ & $0.20 * *$ & - \\
\hline
\end{tabular}

$\mathrm{DS}=$ days to mid-silking; DA = days to mid-anthesis; ASI = anthesis-silking interval; GWT = 100-grain weight; $\mathrm{YLD}=$ grain yield. $* *$ Highly significant; *significant; NS = non-significant.

\section{Hundred-grain weight (g)}

The data presented in Table 2 indicate highly significant $(\mathrm{P} \leq 0.01)$ differences for 100 -grain weight in $\mathrm{C}_{0}$, while significant differences $(\mathrm{P} \leq 0.05)$ were observed in $\mathrm{C}_{1}$. Moderate heritability was observed for grain weight in both cycles (Table 2). The population mean of $25.26 \mathrm{~g}$ and mean of selected HS lines of $25.93 \mathrm{~g}$ were observed in $\mathrm{C}_{0}$. Similarly, the population mean of $27.33 \mathrm{~g}$ and mean of selected HS lines of $28.31 \mathrm{~g}$ were observed in $\mathrm{C}_{1}$ (Table 3 ). The selection differential and Re observed in $\mathrm{C}_{0}$ were 0.67 and $0.39 \mathrm{~g}$, and 0.98 and $0.41 \mathrm{~g}$ in $\mathrm{C}_{1}$, respectively (Table 2 ). An Ro of $0.67 \mathrm{~g}$ was observed for 100 -grain weight (Table 3 ). The gain per cycle for grain weight was $8.19 \%$ (Table 3 ). The 100 -grain weight in both cycles was positively and highly significantly correlated with grain yield (Table 4).

\section{Grain yield (kg/ha)}

The grain yield ANOVA revealed highly significant variations $(\mathrm{P} \leq 0.01)$ among HS lines in $\mathrm{C}_{0}$ and $\mathrm{C}_{1}$ (Table 2). Heritability of 0.74 and 0.64 was revealed for grain yield in $\mathrm{C}_{0}$ and $\mathrm{C}_{1}$, respectively (Table 2). The population mean and mean of selected HS lines for grain yield were 3150.61 and $4077.83 \mathrm{~kg} / \mathrm{ha}$ in $\mathrm{C}_{0}$, respectively; likewise in $\mathrm{C}_{1}$, the population mean of $3309.26 \mathrm{~kg} / \mathrm{ha}$ and mean of selected HS lines of $3949.10 \mathrm{~kg} / \mathrm{ha}$ were observed. The selection differential and $\mathrm{Re}$ for grain yield in $\mathrm{C}_{0}$ were 927.22 and $681.76 \mathrm{~kg} / \mathrm{ha}$, respectively. Similarly in $\mathrm{C}_{1}$, the selection differential was $639.84 \mathrm{~kg} / \mathrm{ha}$ and the expected response was $410.20 \mathrm{~kg} / \mathrm{ha}$ (Table 2). A greater Ro of $815.74 \mathrm{~kg} / \mathrm{ha}$ compared to the expected $681.76 \mathrm{~kg} / \mathrm{ha}$ was observed for grain yield. The gain per cycle observed for grain yield was $5.05 \%$ (Table 3 ). The coefficients of variation 18.36 and $14.49 \%$ were observed in both $C_{0}$ and $C_{1}$, respectively (Table 4).

\section{DISCUSSION}

\section{Flowering traits}

Maize is a monoecious plant where male and female flowers are present on the same plant at different positions, with male flower (tassel) at the top and the female flower (ear) centrally located. Flowering traits measured included days to mid-tasseling, mid-silking, and mid-anthesis. To measure the synchronization of male and female flowers, the ASI was ascertained by subtracting days to mid-anthesis from days to mid-silking. Maturity is an important 
character in plants; along with days to mid-anthesis and to silking, the days to tasseling determine the duration of maturity of plants. The results revealed highly significant variation among HS families for days to mid-silking, anthesis, and ASI in both cycles. These results are in agreement with those of Hidayat et al. (2006), who observed highly significant differences for mid-anthesis and silking while evaluating the performance of local and exotic inbred lines of maize under agro-ecological conditions in Peshawar. Carlone Jr. and Russell (1989) observed similar results in testcross evaluation of maize synthetic BSSS lines. Akbar et al. (2008) also reported significant differences for days to mid-silking while evaluating 3-way crosses of maize through genetic variability, broad-sense heritability, character association, and path analysis. Similarly, other authors estimated significant differences for flowering traits among their experimental material (Rahman et al., 2005).

A short ASI is desirable because it has been reported that a short ASI increases maize tolerance to stress during flowering and ensures good grain filling (Edmeades et al., 1993; Bolaños and Edmeades, 1996). A negative ASI indicates protandry, i.e., silks emerge after pollen shed, whereas a positive ASI indicates protogyny, i.e., silks emerge before pollen shed. In both cases, as the value for ASI diverges from zero, there would be disparity between the time for silking and pollen shed, which is undesirable. A low coefficient of variation was observed for days to mid-tasseling, mid-silking, and mid-anthesis in both $\mathrm{C}_{0}$ and $\mathrm{C}_{1}$, which demonstrated the reliability of the data. Our findings were in agreement with that of Ajala et al. (2009) and Akbar et al. (2008). They also reported a low coefficient of variation for days to mid-silking. After 2 cycles of HS RS, the gain per cycle observed for days to mid-tasseling, silking, and anthesis was $2.99,3.08$, and $3.85 \%$, respectively. High and moderate heritability was observed for maturity traits, indicating low environmental variance and more genetic variance. Our findings for days to mid-silking were in agreement with those of Ajala et al. (2009) when comparing predicted responses to 3 types of RS procedures for the improvement of a maize population. Akbar et al. (2008), Bekavac et al. (2006), Wolf et al. (2000), and Keeratinijakal and Lamkey (1993) also reported similar results. In contrast, Salami et al. (2007) observed low heritability for days to mid-silking and anthesis. The low selection differential demonstrated that progress was made for maturity traits. A possible reason for the low selection differential is that the selection was specifically practiced for yield and maturity traits. A positive and highly significant correlation was found among the flowering traits in both cycles. In $\mathrm{C}_{0}$, days to mid-anthesis was positively and highly significantly correlated with grain yield, while a significant positive correlation was observed between days to mid-silking and grain yield. Galarreta and Álvarez (2007) observed a highly significant (0.92) positive correlation between days to mid-silking and grain yield. Flowering traits were negatively correlated with grain yield in $\mathrm{C}_{1}$. Our results are in accordance with those of Bekavac et al. (2008), who also reported a negative correlation between ASI and grain yield.

\section{Hundred-grain weight (g)}

Grain weight, an important yield component, has a direct effect on the grain yield of maize. The grain weight has a remarkable role in increasing grain yield in relation to other yield-related components (Manivannan, 1998). Highly significant $(\mathrm{P} \leq 0.01)$ differences were observed for 100-grain weight in $\mathrm{C}_{0}$, while significant differences $(\mathrm{P} \leq 0.05)$ were observed in 
$\mathrm{C}_{1}$. Our results were in line with those of Abou-Dief (2007), Mahmood et al. (2004a), Khan et al. (2003), and Alvi et al. (2003), who also reported highly significant differences for grain weight. Moderate heritability estimates were observed for grain weight in both $\mathrm{C}_{0}$ and $\mathrm{C}_{1}$. Ojo et al. (2006), Mahmood et al. (2004b), and Alvi et al. (2003) observed high heritability for grain weight. The population mean of $25.26 \mathrm{~g}$ and mean of selected HS lines of $25.93 \mathrm{~g}$ were observed in $\mathrm{C}_{0}$. Likewise, the population mean of $27.33 \mathrm{~g}$ and mean of selected HS lines of $28.31 \mathrm{~g}$ were revealed in $\mathrm{C}_{1}$. The difference between the means of the selected lines and the population resulted in selection differentials of 0.67 and $0.98 \mathrm{~g}^{\text {in }} \mathrm{C}_{0}$ and $\mathrm{C}_{1}$, respectively. The Re observed in $\mathrm{C}_{0}$ was $0.39 \mathrm{~g}$. Similarly in $\mathrm{C}_{1}$, the Re was $0.41 \mathrm{~g}$.

The 100-grain weight in both cycles was positively and highly significantly correlated with grain yield. Mahmood et al. (2004b) reported similar findings in genetic studies for highyield maize in Chitral Valley. In contrast, Ojo et al. (2006) reported a negative correlation between 100-grain weight and grain yield.

\section{Grain yield (kg/ha)}

Increased grain yield is the main objective of every plant breeding program. Grain yield in maize is the most complex character with which a plant breeder works and is controlled by other yield factors such as grain weight, grain rows per ear, ear length, ear diameter, and prolificacy. Therefore, selection for desirable genotypes should be made based on grain yield as well as other yield components that could influence the yield. The grain yield ANOVA revealed highly significant variations $(\mathrm{P} \leq 0.01)$ among $\mathrm{HS}$ lines in both $\mathrm{C}_{0}$ and $\mathrm{C}_{1}$. Our results also confirmed the findings of Rahman et al. (2007), who also reported highly significant differences for yield components while comparing original and selected maize populations for grain yield traits. Similarly, Sharifi et al. (2009), Badu-Apraku et al. (2008), Menkir and Kling (2007), and Doerksen et al. (2003) observed highly significant differences for grain yield. The population mean and mean of selected HS families for grain yield in $\mathrm{C}_{0}$ were 3150.61 and $4077.83 \mathrm{~kg} / \mathrm{ha}$, respectively. Similarly in $\mathrm{C}_{1}$, the population mean of $3309.26 \mathrm{~kg} / \mathrm{ha}$ and mean of selected HS families of $3949.10 \mathrm{~kg} / \mathrm{ha}$ were observed for grain yield.

Maximum yield ( $6932.50 \mathrm{~kg} / \mathrm{ha}$ ) was produced by HS-51 and minimum yield (1259.00 $\mathrm{kg} / \mathrm{ha}$ ) was produced by HS-40 in $\mathrm{C}_{0}$, similarly in $\mathrm{C}_{1}$, maximum yield $(4419.50 \mathrm{~kg} / \mathrm{ha})$ was produced by HS-120 and minimum yield $(1564.50 \mathrm{~kg} / \mathrm{ha})$ was produced by HS-45. A high heritability of 0.74 and 0.64 for grain yield was revealed in $\mathrm{C}_{0}$ and $\mathrm{C}_{1}$, respectively. The heritability estimate decreased because of a decrease in genetic variance, demonstrating stability in the population. Weyhrich et al. (1998) and Betrán and Hallauer (1996) reported moderate heritability for HS and BSSSCO x BSCB1C0, respectively. Similarly, Santos et al. (2005) also observed high heritability (65.63) in $\mathrm{C}_{0}$ and low heritability (56.61) in $\mathrm{C}_{3}$. The selection differential for grain yield in $\mathrm{C}_{0}$ and $\mathrm{C}_{1}$ was 927.22 and $639.84 \mathrm{~kg} / \mathrm{ha}$, respectively. Weyhrich et al. (1998) observed a 0.67 selection differential for grain yield $(\mathrm{mg} / \mathrm{ha})$ while comparing responses to $7 \mathrm{RS}$ methods in a BS11 maize population. The Re for grain yield in $\mathrm{C}_{0}$ was 681.76 and $410.20 \mathrm{~kg} / \mathrm{ha}$ in $\mathrm{C}_{1}$. The greater Ro for grain yield compared to the Re demonstrated the usefulness of selection for grain yield. Santos et al. (2005) reported a $6.76 \%$ Re for grain yield (g/plant). The gain per cycle observed for grain yield was 5.05\%, demonstrating that grain yield was increased by $5.05 \%$ after 2 cycles of HS RS. 


\section{REFERENCES}

Abou-Dief MH (2007). Estimation of gene effects on some agronomic characters in five hybrids and six populations of maize (Zea mays L.). World J. Agri. Sci. 3: 86-90.

Ajala SO, Ago CE and Olaoye G (2009). Comparison of predicted responses to three types of recurrent selection procedures for the improvement of a maize (Zea mays L.) population. J. Plant Breed. Crop Sci. 1: 284-292.

Akbar M, Shakoor MS, Hussain A and Sarwar M (2008). Evaluation of maize 3-way crosses through genetic variability, broad sense heritability, characters association and path analysis. J. Agric. Res. 46: 39-45.

Alam B (1999). Comparison of $\mathrm{S}_{1}$ Testcrosses Evaluation After a Cycle of $\mathrm{S}_{1}$ Selection in Maize (Zea mays L.). M.Sc. (Hons) thesis, N.W.F.P Agricultural University Peshawar, Pakistan.

Alvi MB, Rafique M, Tariq MS, Hussain A, et al. (2003). Character association and path coefficient analysis of grain yield and yield components maize (Zea mays L.). Pak. J. Biol. Sci. 6: 136-138.

Badu-Apraku B, Fakorede MAB and Lum AF (2008). S family selection in early-maturing maize populations in StrigaInfested and Striga-Free environments. Crop Sci. 48: 1984-1994.

Beavis WD, Smith OS, Grant D and Fincher R (1994). Identification of quantitative trait loci using a small sample of topcrossed and $\mathrm{F}_{4}$ progeny from maize. Crop Sci. 34: 882-896.

Bekavac G, Jocković Đ and Purar B (2006). Genetic analysis of drought adaptive traits in maize synthetic populations. Genetika 38: 215-225.

Bekavac G, Purar B and Jocković Đ (2008). Relationships between line per se and testcross performance for agronomic traits in two broad-based populations of maize. Euphytica 162: 363-369.

Betrán FJ and Hallauer AR (1996). Characterization of interpopulation genetic variability in three hybrid maize populations. J. Hered. 87: 319-928.

Bolaños J and Edmeades GO (1996). The importance of the anthesis-silking interval in breeding for drought tolerance in tropical maize. Field Crops Res. 48: 65-80.

Carangal VR, Ali SM, Koble AF, Rinke EH, et al. (1971). Comparison of $\mathrm{S}_{1}$ with testcross evaluation for recurrent selection in maize. Crop Sci. 11: 658-661.

Carlone MR Jr and Russell WA (1989). Evaluation of $\mathrm{S}_{2}$ maize lines reproduced for several generations by random mating within lines. II. Comparisons for testcross performance of the original and advanced $\mathrm{S}_{2}$ and $\mathrm{S}_{8}$ lines. Crop Sci. 29: 899-904.

Carson ML, Stuber CW and Senior ML (2004). Identification and mapping of quantitative trait loci conditioning resistance to southern leaf blight of maize caused by Cochliobolus heterostrophus Race O. Phytopathology 94: 862-867.

Chaudhary AH (1983). Effect of population and control of weeds with herbicides in maize. Field Crop Abst. 35: 403.

CIMMYT (1981). CIMMYT Review. Centro Internacional de Mejoramiento de Maiz y Trigo. EI Batan.

Doerksen TK, Kannenberg LW and Lee EA (2003). Effect of recurrent selection on combining ability in maize breeding populations. Crop Sci. 43: 1652-1658.

Edmeades GO, Bolanos J, Hernandez M and Bello S (1993). Causes for silk delay in a lowland tropical maize population. Crop Sci. 33: 1029-1035.

Eyherabide GH and Hallauer AR (1991). Reciprocal full-sib recurrent selection in maize: I direct and indirect responses. Crop Sci. 31: 952-959.

Galarreta JIR and Álvarez A (2007). Six cycles of $\mathrm{S}_{1}$ recurrent selection in two Spanish maize synthetics. Spanish J. Agri. Res. 5: 193-198.

Guimarães PE (2001). Effect of Long Term Recurrent Selection Program on the Genetic Structure of BSSS Maize Population. PhD. thesis, Iowa State University, Ames.

Helms TC, Hallauer AR and Smith OS (1989). Genetic drift and selection program in maize. Crop Sci. 29: 602-607.

Hidayat U, Khalil IH, Hassan G, Iltaf U, et al. (2006). Performance of local and exotic inbred lines of maize under agroecological conditions of Peshawar. Sarhad J. Agric. 22: 409-414.

Keeratinijakal V and Lamkey KR (1993). Response to reciprocal recurrent selection in BSSS and BSCB1 maize population. Crop Sci. 33: 73-77.

Khalil IA and Jan A (2002). Cropping Technology. Printed by Mehmood Brothers Printers. Gawalmandi, Rawalpindi.

Khan K, Iqbal M, Shah Z, Ahmad B, et al. (2003). Grain and stover yield of corn with varying times of plant density reduction. Pak. J. Bio. Sci. 6: -1641.

Khan TA (2004). Inbreeding Depression for Yield and Various Genetic Traits in S1 Lines of Maize. Master's thesis, N.W.F.P. Agricultural University, Peshawar.

Lamkey KR (1992). Fifty years of recurrent selection in the Iowa stiff stalk synthetic maize population. Maydica 37: 19-28.

Lush JL (1940). Intra-sire correlations or regressions of offspring on dam as a method of estimating heritability of characteristics. J. Anim. Sci. 1940: 293-301. 
Mahmood Z, Malik SR, Akhtar R and Rafique T (2004a). Heritability and genetic advance estimates from maize genotypes in Shishi Lusht a valley of Krakurm. Int. J. Agri. Biol. 6: 790-791.

Mahmood Z, Ajmal SU, Jilani G, Irfan M, et al. (2004b). Genetic studies for high yield of maize in Chitral valley. Int. J. Agri. Biol. 6: 788-789.

Manivannan NA (1998). Character association and components analysis in maize. Madras J. Agric. 85: 293-294.

Menkir A and Kling JG (2007). Response to recurrent selection for resistance to Striga hermonthica (Del.) benth in a tropical maize population. Crop Sci. 47: 674-682.

Milles JW, Dudley JW, White DG and Lambert RJ (1980). Improving corn population for grain yield and resistance to leaf blight and stalk rot. Crop Sci. 20: 247-250.

Ojo DK, Omikunle OK, Oduwaye OA and Ajala MO (2006). Heritability, character correlation and path coefficient analysis among six inbred-lines of maize (Zea mays L.). World J. Agri. Sci. 2: 352-358.

Penny LH and Elbert SA (1971). Twenty years of reciprocal recurrent selection with two synthetic varieties of maize (Zea mays L.). Crop Sci. 11: 900-903.

Rahman H, Raziq F and Ahmad S (2005). Screening and evaluation of maize genotypes for southern leaf blight resistance and yield performance. Sarhad J. Agric. 21: 231-235.

Rahman H, Khalil IH, Islam N, Durrishahwar, et al. (2007). Comparison of original and selected Maize populations for grain yield traits. Sarhad J. Agric. 23: 641-644.

Salami AE, Adegoke SAO and Adegbite OA (2007). Genetic variability among maize cultivars grown in Ekiti-State, Nigeria. Middle-East J. Sci. Res. 2: 09-13.

Santos MF, Moro GV, Aguiar AM and de Souza Jr CL (2005). Responses to reciprocal recurrent selection and changes in genetic variability in IG-1 and IG-2 maize populations. Genet. Mol. Biol. 28: 781-788.

Sharifi RS, Sedghi M and Gholipouri A (2009). Effect of population density on yield and yield attributes of maize hybrids. Res. J. Biol. Sci. 4: 375-379.

Tanner AH and Smith OS (1987). Comparison of half-sib and S1 recurrent selection in the krug yellow dent maize populations. Crop Sci. 27: 509-513.

Weyhrich RA, Lamkey KR and Hallauer AR (1998). Responses to seven methods of recurrent selection in the BS11 maize population. Crop Sci. 38: 308-321.

Wolf DP, Peternelli LA and Hallauer AR (2000). Estimates of genetic variance in an $\mathrm{F}_{2}$ maize population. J. Hered. 91: 384-391. 